\title{
The snow cover on lakes of the Arctic Coastal Plain of Alaska, U.S.A.
}

\author{
Matthew STURM, ${ }^{1}$ Glen E. LISTON ${ }^{2}$ \\ ${ }^{1}$ U.S. Army Cold Regions Research and Engineering Laboratory, Alaska Projects Office, Bldg 4070, Fort Wainwright, Alaska 99703-0170, U.S.A. \\ E-mail:msturm@crrel.usace.army.mil \\ ${ }^{2}$ Department of Atmospheric Science, Colorado State University, Fort Collins, Colorado 80523, U.S.A.
}

\begin{abstract}
Shallow lakes cover $>25 \%$ of Alaska's Arctic Coastal Plain. These remain frozen and snow-covered from October to June. The lake snow is thinner, denser, harder and has less water equivalent than snow on the surrounding tundra. It contains less depth hoar than land snow, yet paradoxically is subject to stronger temperature gradients. It also has fewer layers and these have been more strongly affected by wind. Dunes and drifts are better developed on lakes; they have wavelengths of $5-20 \mathrm{~m}$, compared to $<5 \mathrm{~m}$ on land. Because of these differences, lake snow has roughly half the thermal insulating capacity of land snow. The winter mass balance on lakes is also different because (1) some snow falls into the water before the lakes freeze, (2) some snow accumulates in drifts surrounding the lakes, and (3) prevailing winds lead to increased erosion and thinner snow on the eastern lake sides. Physical models that extrapolate land snow over lakes without appropriate adjustments for depth, density, distribution and thermal properties will under-predict ice thickness and winter heat losses.
\end{abstract}

\section{INTRODUGTION}

Alaska's Arctic Coastal Plain (ACP) is covered by numerous shallow lakes that are generally elongated perpendicular to the prevailing wind (Fig. 1) (Black and Barksdale, 1949; Carson and Hussey, 1962; Black, 1969; Sellman and others, 1975). These lakes range in size from a few tens of meters in diameter to $>10 \mathrm{~km}$ long. Some of the largest lakes cover $>3000$ ha. Estimates vary, but at a minimum the lakes cover $25 \%$ of the ACP (Sellman and others, 1975), an area of $>27000 \mathrm{~km}^{2}$.

Lakes of the ACP have a thermal origin: thawing of icerich permafrost leads to a reduction in soil volume, creating a basin that fills with water. Lake elongation and preferred orientation, initially a puzzling phenomenon, is now widely accepted to be caused by interactions between lake currents and soil thermal processes, with the prevailing wind providing the orientation (Carson and Hussey, 1962). Despite receiving considerable attention in summer, we know little about the winter regime of the lakes and their associated snow cover. This is unfortunate because the lakes are frozen and covered by snow from October toJune, more than 8 months per year. During that period, the snow insulates the ice and plays a critical role in determining how thick it will grow (Jeffries and others, 1996).

A common assumption has been that lake snow cover is essentially the same as that on the surrounding tundra, but field observations show that there are many important differences. The observations discussed here were begun in 1994 when we started a series of over-snow traverses using snowmobiles in arctic Alaska (Sturm, unpublished data; see also König and Sturm, 1998; Liston and Sturm, 2002; Taras and others, 2002). Differences between lake and land snow covers were impressed upon us literally through the "seat of our pants": the snowmobile ride was bumpier and considerably rougher on the lakes. On tundra, snow-free areas were comparatively rare, while on the lakes they were common. We recognized that the differences in snow would have implications for the thermal regime of the lakes, as well as their winter energy balance and ecology, so between 1996 and 2002 we made paired sets of snow measurements (lake and land) that form the basis of this study.

\section{FIELD AREA AND METHODS}

Measurements were made at 13 paired lake/non-lake stations along a traverse route from Oumalik to Barrow via the village of Atqasuk in northern Alaska (Fig. 1; Table 1). With one exception, the same pairs of sites were measured in April 2000 and April 2002. Lake stations were chosen by plotting straight-line tracks between villages and then selecting lakes intercepted by the track lines. Measurements were made near the middle of lakes and along transects crossing the lakes. Corresponding measurements on land were made far enough away from the lakes to avoid complications resulting from lake-rim snowdrifts, but close enough that regional meteorological variations could be assumed negligible. The sampled lakes range in size from 8 to 906 ha (Table 1); the land surrounding the lakes is mostly flat and covered by tussock tundra.

At each station (lake and land), we measured snow depth using hand or automatic probes (Sturm and Holmgren, 1999) at $0.5 \mathrm{~m}$ intervals along a $100 \mathrm{~m}$ line $(n=201)$. On lakes, depths were accurate to $\pm 0.1 \mathrm{~cm}$; where the probes could penetrate the softer tundra, they were accurate to $\pm 1.5 \mathrm{~cm}$. In 2002, we also measured snow depth at approximately $5 \mathrm{~m}$ intervals along east-west-trending traverse lines $500-3000 \mathrm{~m}$ 


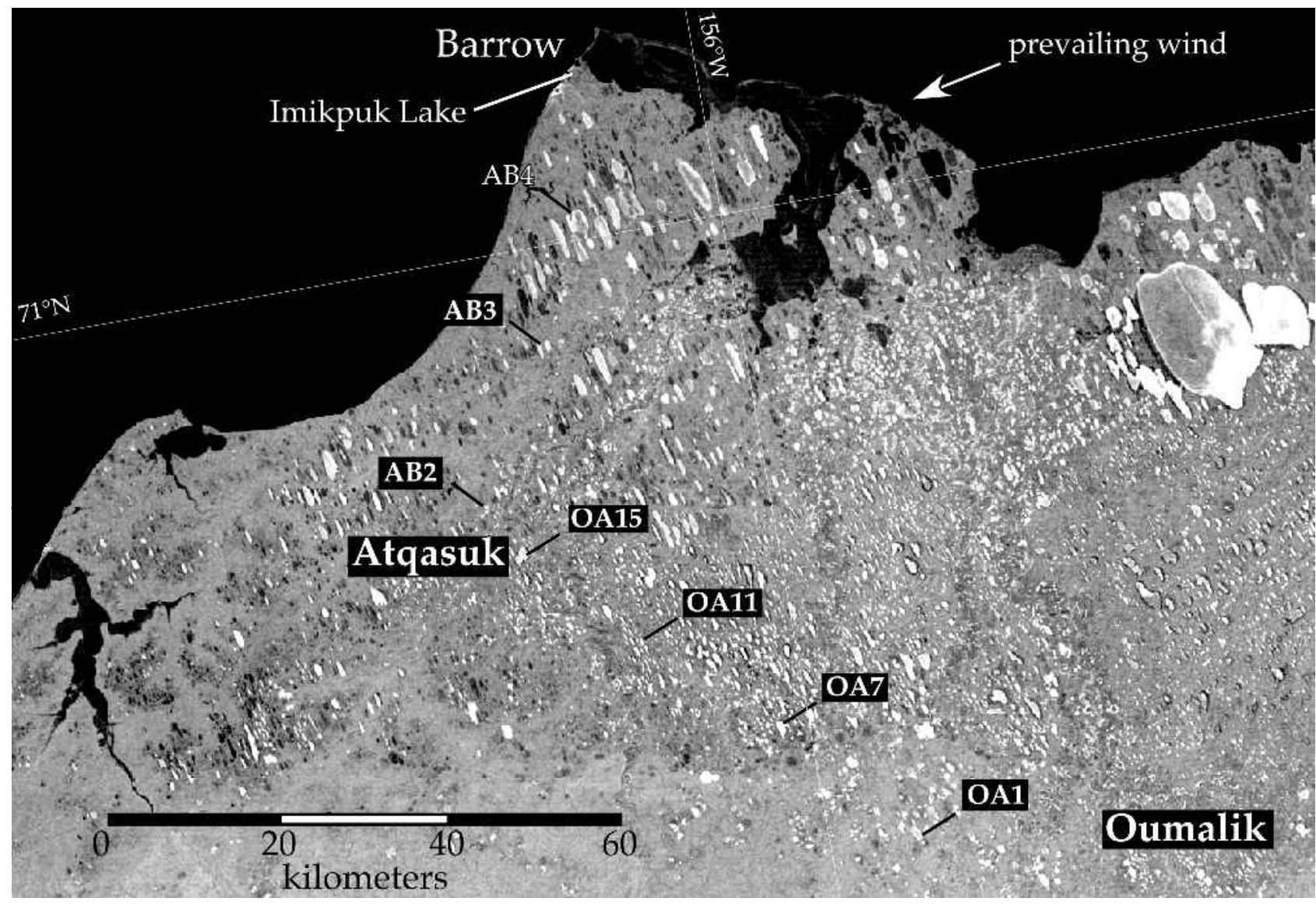

Fig. 1. Image of the Arctic Coastal Plain (ACP) south of Barrow, Alaska, showing the large number of thaw lakes. Several of the stations where measurements were made, including Imikpuk Lake, are marked and delineate the traverse route of 2000 and 2002.

long. Where possible, these lines crossed the lakes from one shore to the other. We measured bulk snow density and snow water equivalent (SWE) at 10 locations along $100 \mathrm{~m}$ lines by collecting snow cores using an aluminum auger (a Federal sampler) with a cross-sectional area of $11.5 \mathrm{~cm}^{2}$. Cores were weighed on a digital balance $( \pm 0.01 \mathrm{~g})$. In addition, snow stratigraphy was measured in five snow pits spaced evenly along the $100 \mathrm{~m}$ line. We used one of these snow pits as an intensive measurement site where we measured the density of each snow layer in duplicate, using a $100 \mathrm{~cm}^{3}$ cutter and a digital balance. In addition, we bracketed this snow pit with two Federal sampler cores. Summing the thickness-density products for each layer and dividing by the total snow depth allowed us to compute the snow-pit bulk density. This was compared to the bulk density determined by coring. Results indicate core-based bulk densities were $4 \%$ lower than pit densities in $2000\left(n=62 ; r^{2}=0.98\right)$ and $10 \%$ lower in 2002 $\left(n=27 ; r^{2}=0.98\right)$. We have corrected the core densities and SWE values reported here by these amounts.

In the main snow pit, we also measured the grain-size, grain type, hardness (using the traditional "fist-fingerpencil-knife" criterion) and resistance to penetration of each snow layer. The latter was measured using a springloaded device that recorded the resistance to a plate penetrating the side-wall of a snow pit. One of four different plate areas (in ratios of $1: 10: 100: 1000$ ) was selected for use based on snow strength. The penetration pressure ( $\mathrm{MPa})$, defined as the pressure at which point the snow face gave way and the selected plate collapsed into the snow, is reported here. In many cases, based on layer characteristics and sequence, a direct 1:1 correspondence was established between layers of snow on land and on the nearby lake, thereby allowing direct comparison of snow strength and characteristics between the two.

Unlike many lower-latitude snow covers, the ACP snow cover experiences extremely strong temperature gradients $\left(>0.3^{\circ} \mathrm{C} \mathrm{cm}^{-1}\right)$ and high vertical heat-flow rates for prolonged periods ( $>100$ days). These result in high rates of water vapor transport and rapid snow metamorphism (Sturm and Benson, 1997), producing extreme forms of depth hoar. Even wind-slab layers of $>0.4 \mathrm{~g} \mathrm{~cm}^{-3}$ density metamorphose into a depth-hoar-like material exhibiting kinetic growth forms (Colbeck, 1986), somewhat in contra-
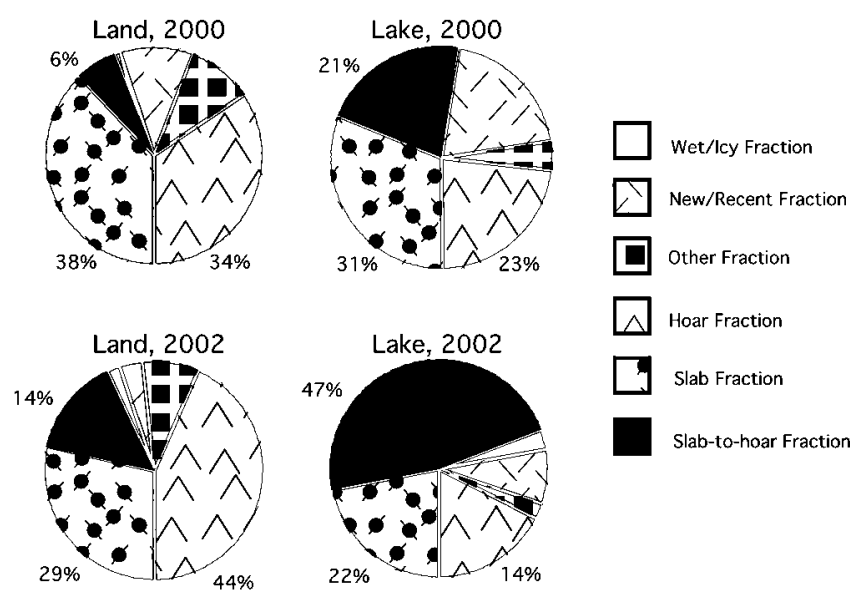

$\triangle$ Hoar Fraction

Fig. 2. The textural composition of the snow cover on lakes and land, 2000 and 2002. 
Slab-to-hoar fraction
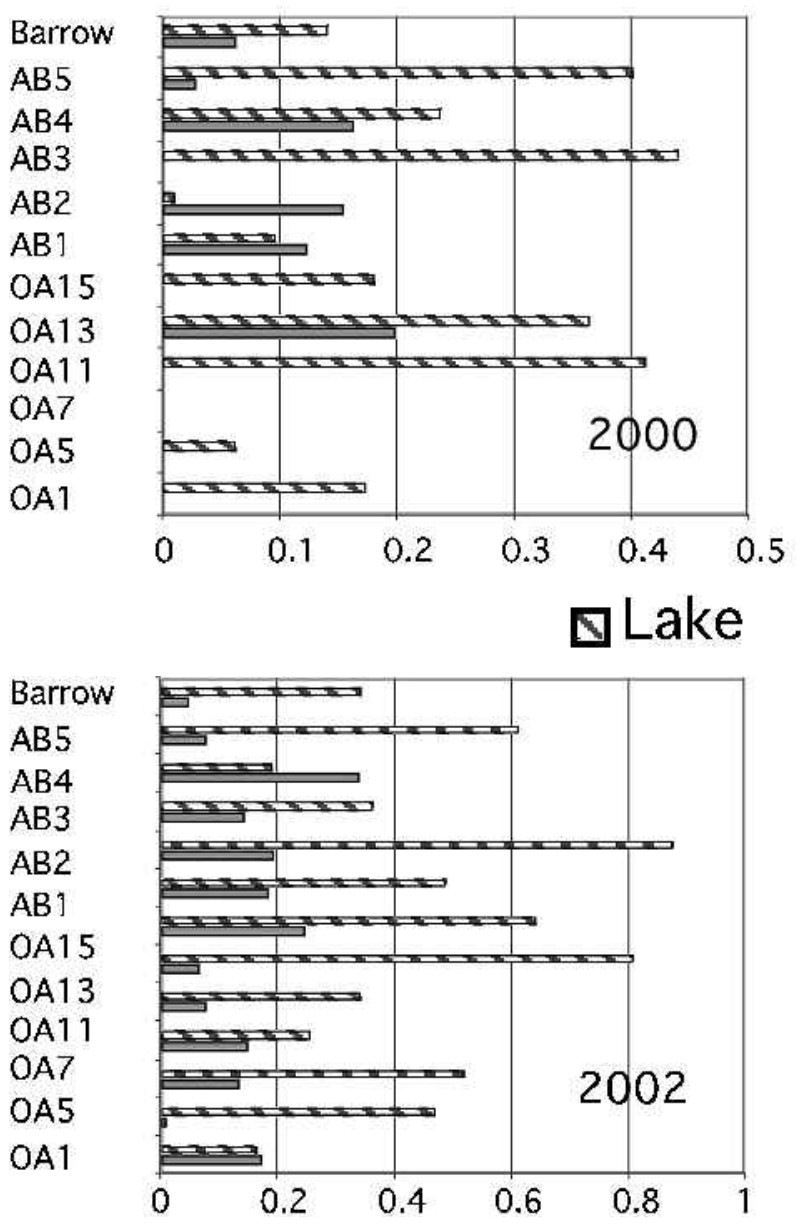

Depth-hoar fraction
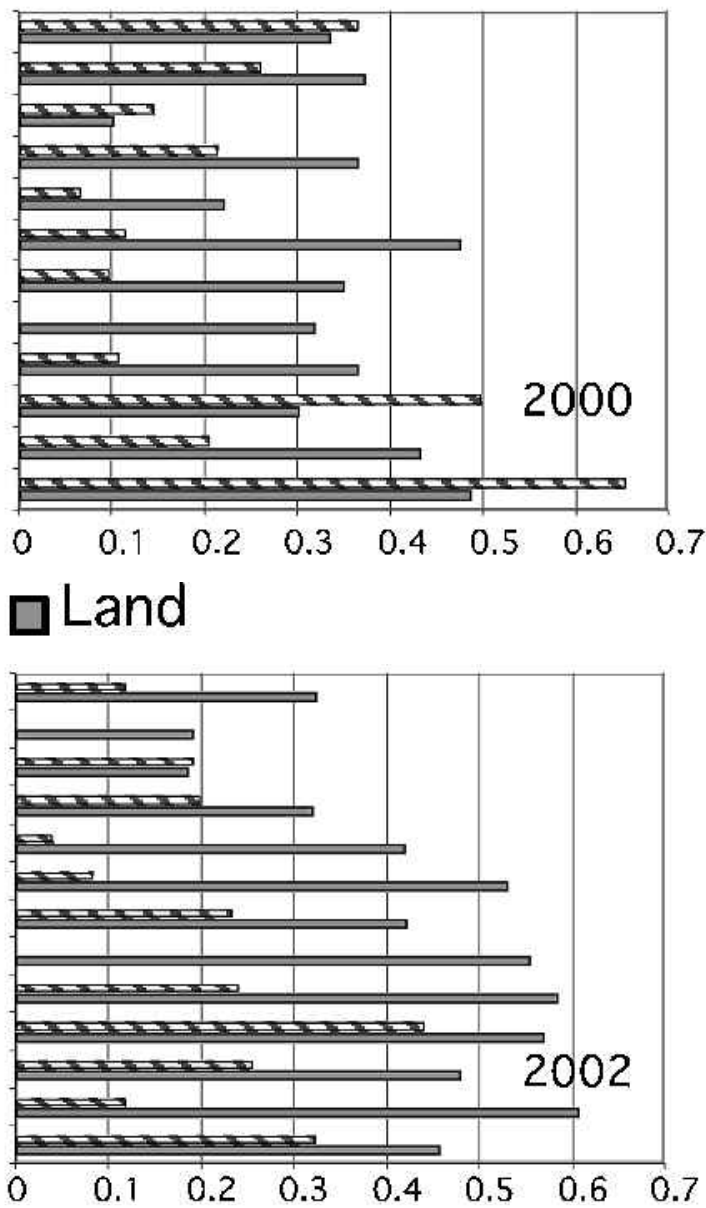

Fig. 3. Histograms showing lake and land snow slab-to-hoar and depth-hoar fractions by station.

diction to Akitaya's (1974) finding that depth-hoar metamorphism is minimal in high-density snow. For classifying snow types within each layer in this study, we used the International Classification for Snow on the Ground (Colbeck and others, 1990), but have added one additional type of snow: slab-to-hoar, a compact layer of snow exhibiting the cohesiveness of a wind slab but consisting of snow grains with kinetic growth features and depth-hoar grains.

In addition to the Oumalik-Barrow traverses, over-snow traverses were conducted in 1996 and 1997 in the Kuparuk Basin south of Prudhoe Bay, Alaska, a region about $400 \mathrm{~km}$ east of the Oumalik-Barrow line. During these traverses, in addition to our standard measurements, we surveyed $100 \mathrm{~m}$ long snow surface profiles using a rotating laser and self-reading rod accurate to $\pm 2 \mathrm{~cm}$. Using a snow radar (Holmgren and others, 1998), we measured closely spaced $(\sim 0.1 \mathrm{~m})$ snow depths along traverse lines up to $1 \mathrm{~km}$ long on both lake and land to examine snow-cover surface and subsurface roughness.

\section{RESULTS}

We found five snow-cover characteristics that were distinctly different between lakes and land.

\section{Gharacteristic 1: Snow depth and SWE}

The snow cover on lakes was thinner, denser and comprised less SWE than on the nearby land (Table 1). Snow depths on lakes were $56 \%$ and $57 \%$ lower than on land in 2000 and
2002, respectively, but lake snow was $21 \%$ denser in both years. Consequently, there was 25\% (in 2000) and 38\% (in 2002) less SWE on lakes than on land. In terms of actual measured SWE values, lakes averaged $7.4 \mathrm{~cm}$ for the two years, while land averaged $9.7 \mathrm{~cm}$. Independent results from two lake-land station pairs measured in the Kuparuk Basin in spring 1997 showed a similar contrast. In this case, snow depth averaged $28 \%$ less on lakes than on land. Similarly, in 2001 at Imikpuk Lake near Barrow (the only lake measured in that year), the lake had $18 \%$ less SWE than on nearby land.

\section{Characteristic 2: Snow stratigraphy and texture}

There were fewer snow layers on the lakes than on land (average for all station pairs $(n=13)$ was 3.5 vs 4.9 in 2000 and 3.4 vs 5.4 in 2002), but individual layers were about the same thickness (7.7 vs $6.9 \mathrm{~cm}$ in 2000; $6.1 \mathrm{vs} 7.0 \mathrm{~cm}$ in 2002). Lake snow had a much higher percentage of slab-to-hoar snow than land snow, while land snow invariably contained a higher percentage of depth hoar (Fig. 2). Wind slabs, in contrast, were represented about equally in both locations. Fine-grained snow and depth hoar cannot metamorphose into snow textures that mimic wind slab or slab-to-hoar, so the textural differences indicate wind slabs were forming on lakes while less dense layers were forming on the tundra. In contrast, the fact that wind slabs turned into slab-to-hoar on the lakes indicates that post-depositional metamorphosis, even of wind-slab layers, was more intense on lakes than on land. These textural 
Table 1. Paired stations where snow was measured on lakes and on nearby land in 2000 and 2002

\begin{tabular}{|c|c|c|c|c|c|c|c|c|c|}
\hline \multirow[t]{2}{*}{ Station } & \multirow[t]{2}{*}{ Date } & \multirow[t]{2}{*}{ Type } & \multirow{2}{*}{$\begin{array}{l}\text { Latitude } \\
{ }^{\circ} \mathrm{N}\end{array}$} & \multirow{2}{*}{$\begin{array}{c}\text { Longitude } \\
{ }^{\circ} \mathrm{W}\end{array}$} & \multirow{2}{*}{$\begin{array}{c}\text { Lake area } \\
\text { ha }\end{array}$} & \multirow{2}{*}{$\begin{array}{l}\text { Snow depth } \\
\text { cm }\end{array}$} & \multirow{2}{*}{$\begin{array}{c}\text { Std dev. } \\
(n=201) \\
\mathrm{cm}\end{array}$} & \multirow{2}{*}{$\begin{array}{l}\text { Density } \\
\mathrm{g} \mathrm{cm}^{-3}\end{array}$} & \multirow{2}{*}{$\begin{array}{c}S W E \\
\mathrm{~cm}\end{array}$} \\
\hline & & & & & & & & & \\
\hline \multirow[t]{4}{*}{ OA-1 } & 29 Mar 2000 & Land & 69.8460 & 155.6612 & 123 & 37.1 & 12.2 & 0.239 & 9.6 \\
\hline & 20 Apr 2002 & Land & & & & 43.6 & 5.5 & 0.292 & 12.6 \\
\hline & 29 Mar 2000 & Lake & & & & 31.4 & 6.9 & 0.342 & 10.9 \\
\hline & 20 Apr 2002 & Lake & & & & 20.6 & 5.8 & 0.355 & 8.8 \\
\hline \multirow[t]{4}{*}{ OA-5 } & 30 Mar 2000 & Land & 69.9830 & 156.0214 & 114 & 35.1 & 10.0 & 0.254 & 11.8 \\
\hline & 20 Apr 2002 & Land & & & & 40.8 & 11.1 & 0.254 & 9.8 \\
\hline & 30 Mar 2000 & Lake & & & & 13.8 & 9.3 & 0.353 & 8.4 \\
\hline & 20 Apr 2002 & Lake & & & & 18.0 & 7.8 & 0.331 & 7.5 \\
\hline \multirow[t]{4}{*}{ OA-7 } & 30 Mar 2000 & Land & 70.0656 & 156.3019 & 906 & 40.2 & 13.7 & 0.286 & 12.7 \\
\hline & 20 Apr 2002 & Land & & & & 40.8 & 11.1 & 0.282 & 12.6 \\
\hline & 30 Mar 2000 & Lake & & & & 22.0 & 11.2 & 0.332 & 11.4 \\
\hline & 20 Apr 2002 & Lake & & & & 25.0 & 7.8 & 0.354 & 8.8 \\
\hline \multirow[t]{4}{*}{ OA-10 } & 30 Mar 2000 & Land & 70.1912 & 156.6296 & 248 & 39.7 & 11.9 & 0.268 & 9.0 \\
\hline & 21 Apr 2002 & Land & & & & 35.1 & 7.5 & 0.269 & 9.8 \\
\hline & 30 Mar 2000 & Lake & & & & 27.8 & 13.4 & 0.352 & 11.0 \\
\hline & 21 Apr 2002 & Lake & & & & 21.1 & 7.8 & 0.328 & 6.4 \\
\hline OA-11 & 31 Mar 2000 & Land & 70.2802 & 156.8555 & 31 & 25.2 & 15.6 & 0.311 & 13.3 \\
\hline & 21 Apr 2002 & Land & & & & 22.7 & 4.8 & 0.197 & 4.7 \\
\hline & 31 Mar 2000 & Lake & & & & 17.0 & 12.9 & 0.352 & 9.3 \\
\hline & 21 Apr 2002 & Lake & & & & 18.0 & 6.3 & 0.328 & 7.3 \\
\hline OA-13 & 31 Mar 2000 & Land & 70.4037 & 157.1651 & 57 & 20.5 & 11.2 & 0.276 & 8.9 \\
\hline & 21 Apr 2002 & Land & & & & 29.2 & 10.5 & 0.282 & 9.8 \\
\hline & 31 Mar 2000 & Lake & & & & 17.8 & 12.1 & 0.390 & 7.9 \\
\hline & 21 Apr 2002 & Lake & & & & 16.2 & 5.1 & 0.356 & 6.6 \\
\hline OA-15 & 01 Apr 2000 & Land & 70.4919 & 157.4584 & 826 & 26.3 & 9.0 & 0.246 & 7.7 \\
\hline & 24 Apr 2002 & Land & & & & 32.5 & 10.6 & 0.265 & 6.8 \\
\hline & 01 Apr 2000 & Lake & & & & 7.1 & 6.1 & 0.341 & 5.3 \\
\hline & 24 Apr 2002 & Lake & & & & 16.1 & 6.4 & 0.332 & 6.5 \\
\hline AB-1 & 02 Apr 2000 & Land & 70.5694 & 157.5786 & 24 & 26.7 & 10.2 & 0.248 & 8.1 \\
\hline & 24 Apr 2002 & Land & & & & 22.9 & 6.5 & 0.251 & 6.6 \\
\hline & $02 \mathrm{Apr} 2000$ & Lake & & & & 15.0 & 9.6 & 0.354 & 7.2 \\
\hline & 24 Apr 2002 & Lake & & & & 13.5 & 6.2 & 0.361 & 6.4 \\
\hline $\mathrm{AB}-2$ & 02 Apr 2000 & Land & 70.6989 & 157.3092 & 122 & 28.6 & 13.4 & 0.294 & 8.5 \\
\hline & $24 \mathrm{Apr} 2002$ & Land & & & & 31.6 & 8.7 & 0.341 & 12.0 \\
\hline & $02 \mathrm{Apr} 2000$ & Lake & & & & 7.6 & 8.5 & 0.312 & 3.7 \\
\hline & 24 Apr 2002 & Lake & & & & 24.7 & 4.7 & & \\
\hline $\mathrm{AB}-3$ & 02 Apr 2000 & Land & 70.8406 & 157.0797 & 219 & 34.9 & 7.8 & 0.308 & 11.5 \\
\hline & $24 \mathrm{Apr} 2002$ & Land & & & & 44.6 & 11.3 & 0.318 & 10.9 \\
\hline & 02 Apr 2000 & Lake & & & & 19.8 & 10.9 & 0.333 & 8.2 \\
\hline & 24 Apr 2002 & Lake & & & & 13.5 & 5.7 & 0.327 & 3.4 \\
\hline $\mathrm{AB}-4$ & 02 Apr 2000 & Land & 71.0622 & 156.8744 & 8 & 24.9 & 9.1 & 0.343 & 9.7 \\
\hline & 25 Apr 2002 & Land & & & & 26.5 & 7.2 & 0.294 & 9.1 \\
\hline & $02 \mathrm{Apr} 2000$ & Lake & & & & 12.2 & 7.1 & 0.363 & 6.2 \\
\hline & 25 Apr 2002 & Lake & & & & 17.3 & 12.9 & 0.270 & 7.2 \\
\hline $\mathrm{AB}-5$ & 02 Apr 2000 & Land & 71.2486 & 156.7814 & 157 & 27.6 & 12.8 & 0.291 & 7.4 \\
\hline & 25 Apr 2002 & Land & & & & 24.5 & 9.6 & 0.253 & 8.3 \\
\hline & $03 \mathrm{Apr} 2000$ & Lake & & & & 18.2 & 9.1 & 0.300 & 7.2 \\
\hline & 25 Apr 2002 & Lake & & & & 16.1 & 6.9 & 0.353 & 6.4 \\
\hline ARM tundra & 06 Apr 2000 & Land & 71.3264 & 156.6197 & & 29.2 & 13.6 & 0.344 & 10.5 \\
\hline & 01 Apr 2001 & Land & & & & 28.7 & 9.2 & 0.321 & 6.8 \\
\hline & 28 Apr 2002 & Land & & & & 28.2 & 9.9 & 0.296 & 9.8 \\
\hline Imikpuk Lake & 05 Apr 2000 & Lake & & & 61 & 11.7 & 8.9 & 0.356 & 6.7 \\
\hline & 01 Apr 2001 & Lake & & & & 9.4 & 7.2 & 0.379 & 5.8 \\
\hline & 28 Apr 2002 & Lake & & & & 19.6 & 5.3 & 0.306 & 6.9 \\
\hline & Average lan & 2000 & & & & 30.5 & 11.6 & 0.285 & 9.9 \\
\hline & Average lan & 2001 & & & & 32.5 & 8.8 & 0.277 & 9.4 \\
\hline & Average lak & 2000 & & & & 17.0 & 9.7 & 0.344 & 7.9 \\
\hline & Average lak & 2001 & & & & 18.4 & 6.8 & 0.334 & 6.8 \\
\hline
\end{tabular}



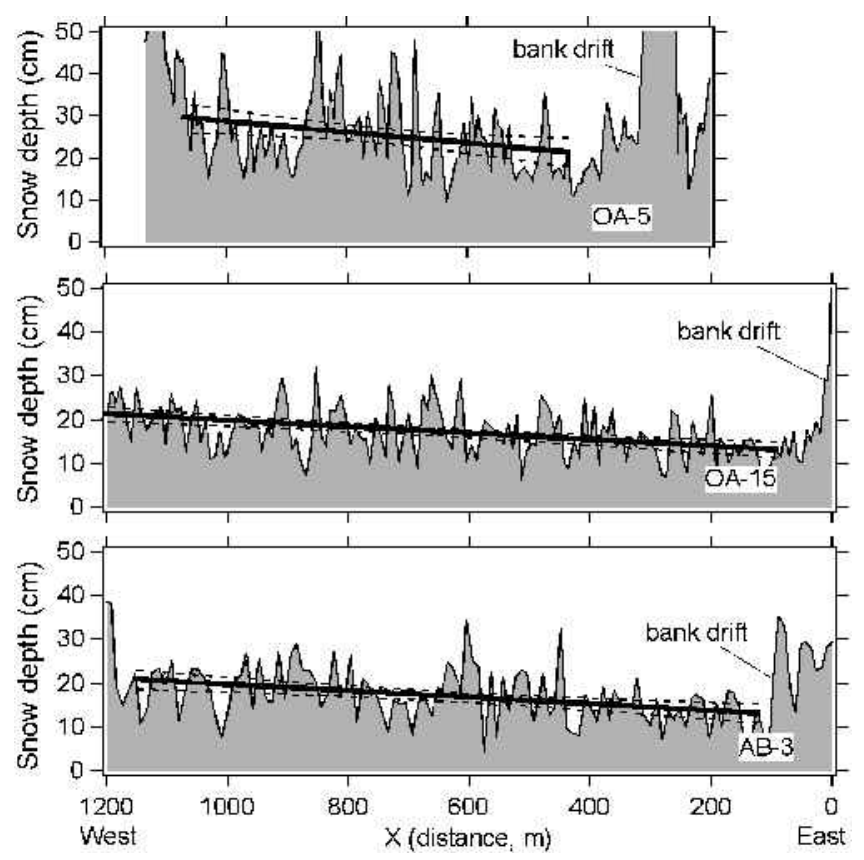

Fig. 4. East-west snow depth profiles across three selected lakes showing increasing depth to the west. The heavy line is a linear fit to the data ( see Table 3 for all regression coefficients). Lighter dashed lines show 95\% confidence limits. The probe line directions were $250^{\circ}$ true for $\mathrm{OA}-15,222^{\circ}$ for $\mathrm{OA}-5$, and $271^{\circ}$ for $A B-3$, similar to that of the prevailing wind.

differences are reflected in the station ensemble averages as well as nearly every individual station pair (Fig. 3).

\section{Gharacteristic 3: Snow hardness}

As might be expected based on snow texture, lake snow was considerably harder than land snow. Comparing layers where we could cross-correlate lake snow strata directly to land snow strata (Table 2), and for which we had spring penetrometer data (2002 only), we found that lake snow layers required an average penetration pressure 14 times greater than the same layers on land. The largest contrasts arose where lake snow was classified as slab-to-hoar and still retained slab characteristics, while the corresponding land snow was classified as depth hoar, a weak and friable material. For the few cases where land snow layers were harder than lake snow, the ratio of penetration pressures (Table 2) ranged from 0.2 to 0.9 , indicating somewhat similar layer strengths. These less-than-one ratios were usually found at the snowcover top, where there had been the least amount of time for snow metamorphism.

\section{Characteristic 4: Spatial distribution of snow depth due to wind}

Lake snow depths increased from east to west, down the prevailing (easterly) wind. Using 2002 depth data taken from long traverse lines (Fig. 4), we have estimated the increase by fitting a line to the depth data using a least-squares procedure. In doing so, we were careful to exclude data from the conspicuous bank drifts that form in the lee of the small $(<1 \mathrm{~m})$ to large $(>10 \mathrm{~m})$ bluffs that typically surround the lakes. The set of linear fits (Table 3 ) show a consistent increase in depth to the west that in most cases is significant at the $95 \%$ confidence level. The data (significant values
Table 2. Layer hardness by spring penetrometer for all lake and land layers that could be cross-correlated; bold values are near 1

\begin{tabular}{|c|c|c|c|c|}
\hline Station & Layer & $\begin{array}{l}\text { Land } \\
\mathrm{MPa}\end{array}$ & $\begin{array}{l}\text { Lake } \\
\mathrm{MPa}\end{array}$ & Lake/land ratio \\
\hline OA-1 & $\mathrm{A}$ & 20.6 & 11.8 & 0.6 \\
\hline OA-1 & $\mathrm{B}$ & 0.5 & 4.9 & 10.4 \\
\hline OA-1 & $\mathrm{D}$ & 0.7 & 88.2 & 120.0 \\
\hline OA-5 & A & 1.0 & 7.4 & 7.7 \\
\hline OA-5 & B & 0.8 & 7.4 & 9.4 \\
\hline OA-5 & $\mathrm{D}$ & 0.3 & 5.9 & 17.1 \\
\hline OA-7 & general & 0.4 & 10.3 & 23.3 \\
\hline OA-10 & general & 0.5 & 7.8 & 16.0 \\
\hline OA-11 & $\mathrm{A}$ & 15.7 & 3.5 & 0.2 \\
\hline OA-11 & B & 0.4 & 3.9 & 8.9 \\
\hline OA-11 & $\mathrm{C}$ & 6.2 & 18.1 & 2.9 \\
\hline OA-11 & $\mathrm{D}$ & 0.6 & 8.8 & 15.0 \\
\hline OA-13 & $\mathrm{B}$ & 10.8 & 14.2 & 1.3 \\
\hline OA-13 & $\mathrm{C}$ & 0.6 & 1.5 & 2.5 \\
\hline OA-15 & general & 3.4 & 20.6 & 6.0 \\
\hline AB-1 & $\mathrm{B}$ & 0.5 & 11.8 & 21.8 \\
\hline AB-1 & $\mathrm{C}$ & 0.4 & 7.8 & 17.8 \\
\hline AB-2 & general & 0.5 & 4.9 & 10.0 \\
\hline AB-3 & $\mathrm{C}$ & 0.7 & 8.8 & 12.9 \\
\hline AB-3 & $\mathrm{B}$ & 6.9 & 18.6 & 2.7 \\
\hline AB- 4 & $\mathrm{D}$ & 7.3 & 3.4 & 0.5 \\
\hline $\mathrm{AB}-4$ & B & 8.8 & 10.3 & 1.2 \\
\hline AB- 5 & $\mathrm{~A}$ & 0.2 & 0.2 & 0.9 \\
\hline AB- 5 & B & 4.4 & 8.8 & 2.0 \\
\hline $\begin{array}{l}\text { Imikpuk- } \\
\text { ARM }\end{array}$ & $\mathrm{E}$ & 0.7 & 12.3 & 17.9 \\
\hline $\begin{array}{l}\text { Imikpuk- } \\
\text { ARM }\end{array}$ & $\mathrm{F}$ & 0.4 & 21.6 & 48.9 \\
\hline Average values: & & 3.6 & 12.4 & 14.5 \\
\hline
\end{tabular}

only) indicate snow-depth gradients of $5-35 \mathrm{~cm}$ per $\mathrm{km}$, with an average gradient of $19 \mathrm{~cm}$ per $\mathrm{km}$. Conspicuously, we found higher gradients where the fitted probe lines started on the lake's east shore than for those that started in the middle or nearer the west shore.

This east-side depletion was more pronounced in 2000 than in 2002. Aerial inspection of more than a dozen lakes south of Barrow in 2000 showed discontinuous snow cover with considerable bare ice exposed predominantly along the eastern lake sides.

\section{Characteristic 5: Snow surface roughness and dunes}

Lake snow had better-developed surface roughness features (basically larger snow dunes) than land snow (Fig. 5a), and the wavelength of these features was longer. Detailed depth profiles taken using an FM-CW radar in 1996 (Holmgren and others, 1998) on a large lake south of Prudhoe Bay and on the adjacent tundra exhibit different power spectral densities (Fig. 5b). The lake snow has larger and more pronounced structures with wavelengths of 5-20 m. These structures are the bumps that make snowmobile travel on lakes less pleasant than on tundra. Wavelengths of land snow features were typically less than a few meters, corresponding to smallscale erosion and deposition features like sastrugi. For wavelengths $>20 \mathrm{~m}$, the roughness of lake and land snow covers converged, but at this scale the land measurements are confounded by local topographic variations as well as snow roughness. 


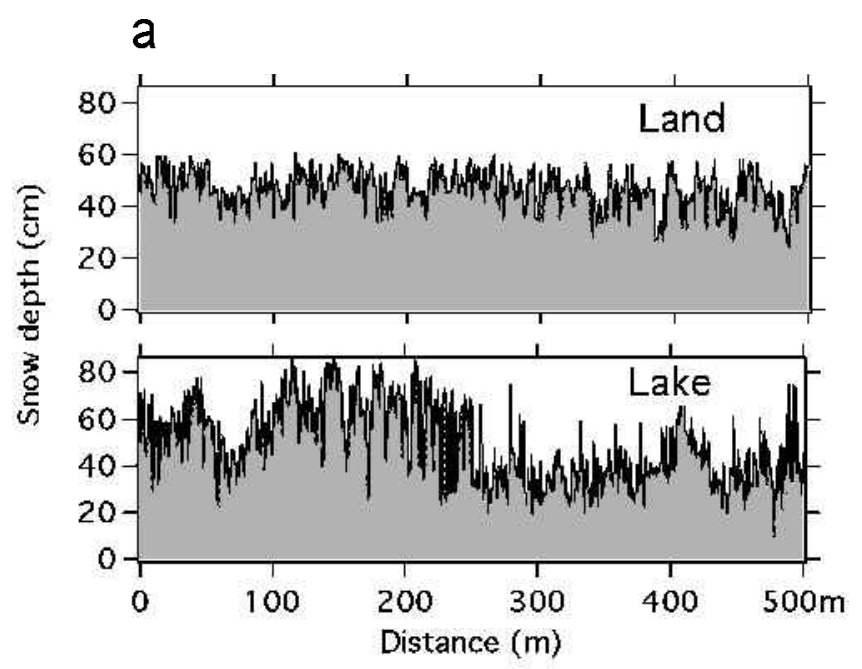

b

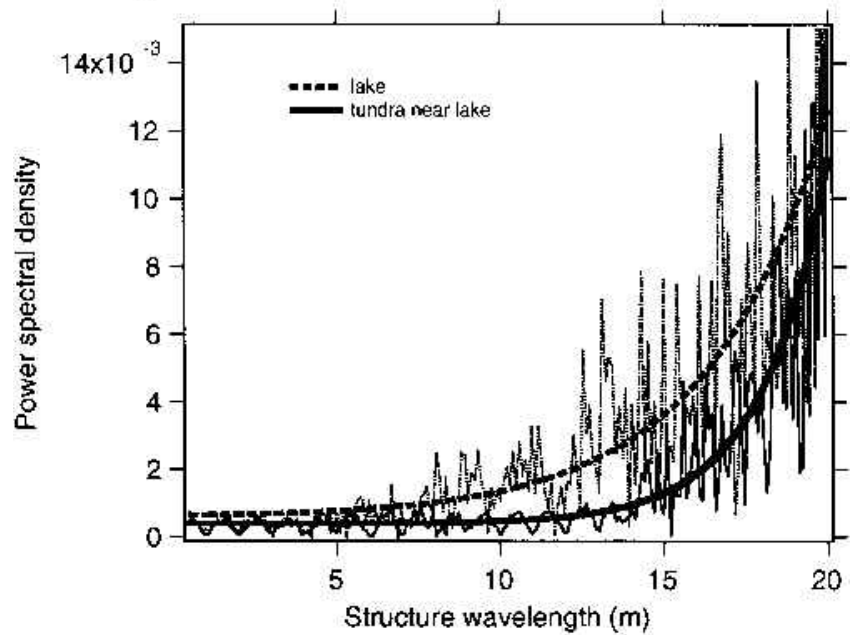

Fig. 5. (a) Snow depth cross-sections for Duk Lake (69 $55^{\prime} \mathcal{N}$, $149^{\circ} 07^{\prime} \mathrm{W}$ ) south of Prudhoe Bay, and for a tundra site near the lake. Data were collected using an FM-CW radar at $0.5 \mathrm{~m}$ spacing on the lake, $0.9 \mathrm{~m}$ spacing on the land. (b) The power spectral density of the snow cover for the cross-sections shown in (a). A curve has been fit to the data for each environment. These show that lake snow has bigger and more pronounced structures at wavelengths of 5-20 m, though it con-verges at greater wavelengths due to local topographic gradients on the land.

The main source of lake snow-depth variation is undulations in the snow surface produced by wind drifting (Fig. 6a), while a substantial component of the tundra snow-depth variation is due to microtopographic relief from tussocks and hummocks (Fig. 6b; see also Sturm and Holmgren, 1994). This tundra relief is often equal to $1 / 3$ or more of the total snow depth. On tundra (Fig. 6b), the snow tends to smooth the substrate relief, while on lakes, where the ice surface is flatter (Fig. 6a), the snow cover tends to roughen the surface. Sturm and others (1998) reported similar findings for snow on Antarctic sea ice.

\section{DISGUSSION}

Four processes critical to the development of a snow cover function differently on ACP lakes than they do on tundra. The first is snow accumulation. Snow begins to fall in late August, but the lakes do not freeze until mid-September

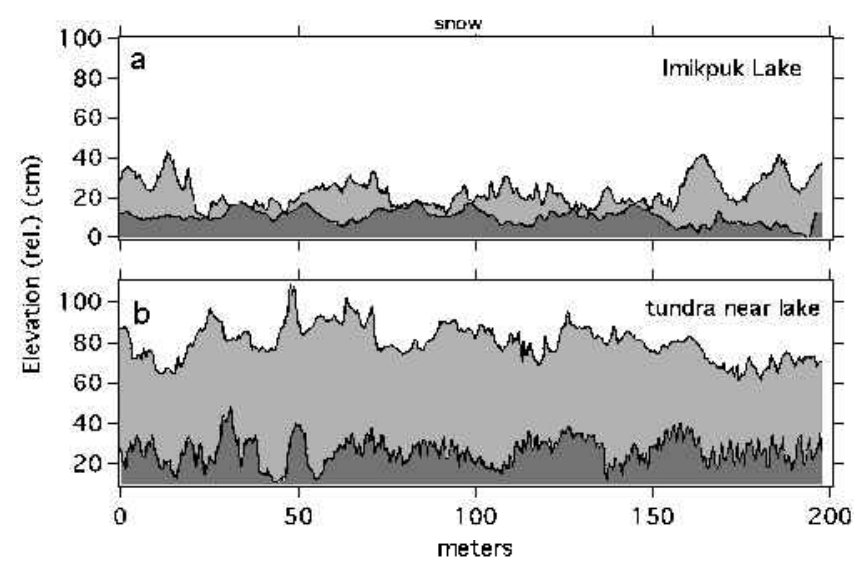

Fig. 6. Cross-sections of the snow cover on a lake (Imikpuk Lake; see Fig. 1) (a) and on the nearby tundra (b) showing the distinctly different basal roughness of the ice vs tundra.

(Brewer, 1958; Jeffries and others, 1996; Liston and Sturm, 2002). The early-season snow falls into the water and is not incorporated in the snow cover. This explains, in part, why there is less SWE on the lakes than on the tundra. However, as discussed below, it cannot explain the full SWE contrast.

The second process is the interaction of surface roughness with wind-blown snow. Tundra tussock and hummock relief (Fig. 6b) traps and immobilizes early-season blowing snow, but on the smooth ice of a recently frozen lake, this snow is more mobile and blows around more. It does so for a much longer period of time, and perhaps at a higher speed. The bigger and harder snow dunes on the lakes (Fig. $5 \mathrm{a}$ and $\mathrm{b})$ are evidence of this enhanced transport. The greater amount of transport results in more dune growth, more pulverized snow grains, and therefore greater sintering (German, 1996) and harder snow (Table 2).

A third factor is vertical temperature gradients, which are consistently greater through the lake snow cover than through tundra snow. The water under the ice provides a latent-heat source that lasts throughout the winter, maintaining snowice interface temperatures several ${ }^{\circ} \mathrm{C}$ higher than land snowground interface temperatures. On land, much of the latent heat associated with unfrozen soil moisture in the active layer is exhausted by mid-winter, so the interface temperatures drop as winter progresses (Sturm and others, 1995; Jeffries and others, 1999; Taras and others, 2002; Olsson and others, 2003). The stronger lake temperature gradients result in more rapid and intense kinetic crystal growth. Although lake snow is deposited harder and more wind-packed, the higher temperature gradients convert much of it to depth hoar, or at least to slab-to-hoar texture (Figs 2 and 3).

Lastly, snow ice can form on lakes but not on land. During early freeze-up, when lake ice is thin, a relatively large snowfall can depress the ice below the water surface, and liquid water will invade the bottom of the snow, saturating it and later refreezing into snow ice (Liston and Hall, 1995). Our stratigraphic data suggest this is a rare process in this area of the Arctic (cf. Bilello and others, 1964; Bilello, 1980; Zhang and Jeffries, 2000), though in regions with greater winter snowfall this could produce important snow-cover differences.

Based on the first process described above, we have estimated the winter mass balance on lakes and contrasted it with that on land. For this comparison, we have assumed that $9.7 \mathrm{~cm}$ of SWE fell during the winter (average SWE value for 


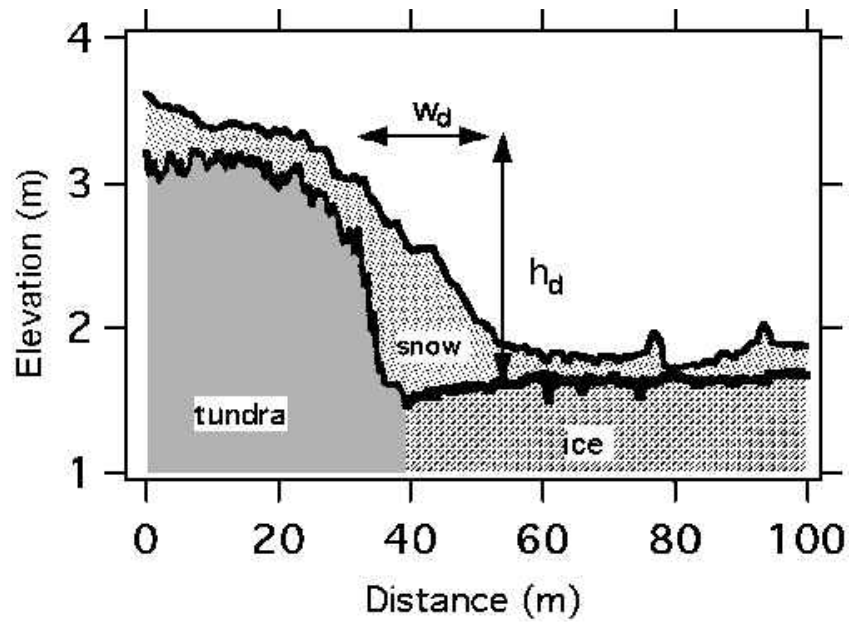

Fig. 7. A snow bank drift at the edge of a lake south of Prudhoe Bay.

land (Table 1)), with $75 \%$ of the accumulation occurring linearly between September and November, and the remaining $25 \%$ occurring at a constant rate in March-April (Olsson and others, 2002), a pattern consistent with our understanding of ACP snowfall timing. Lakes are assumed to develop a snow-bearing ice cover on 15 September (Brewer, 1958; Jeffries and others, 1996; Liston and Sturm, 2002). By that time, $1.1 \mathrm{~cm}$ of SWE has already fallen, so the computed SWE covering the lakes at winter's end should be $8.6 \mathrm{~cm}$, a value that is $1.2 \mathrm{~cm}(16 \%)$ higher than the measured value (Table 1). In order to bring the computed value into line with observations, an additional reduction is needed. For this amount to fall into the water, either the lake would need to freeze as late as 1 October, or $100 \%$ of the accumulation would need to come in September-November, both somewhat unreasonable assumptions. The $16 \%$ mismatch points to some other lake snow sink.

There are three sink possibilities: (1) the snow is trapped in bank drifts surrounding the lakes, (2) there is an additional erosion mechanism on the lakes, or (3) winter sublimation is higher on the lakes. We believe that sublimation is the least significant of these possibilities (discussed below), and therefore focus our discussion on bank drifts and erosion. Using data from Figure 4, along with other snow depth profiles not shown, we can estimate how much snow might be stockpiled in bank drifts. We assume that the lakes are elliptical in shape, with major and minor axes of length $a$ and $b$, and that a drift with a triangular cross-section (Fig. 7) of height $h_{\mathrm{d}}$ and width $w_{\mathrm{d}}$ completely rims each lake. Measured values of $h_{\mathrm{d}}$ and $w_{\mathrm{d}}$ appear in Table 4. Results from Benson and Sturm (1993) and Sturm and others (2001) indicate the drift density $\left(\rho_{\mathrm{d}}\right)$ is higher than lake snow density $\left(\rho_{1}\right)$, so we also account for that difference. Solving for the snow layer thickness $(h$, units of SWE) that would blanket the entire lake surface were the snow not in the drifts, we find:

$$
h=\left(\frac{\rho_{\mathrm{d}}}{\rho_{\mathrm{l}}}\right) \frac{h_{\mathrm{d}} w_{\mathrm{d}} \sqrt{\left[a^{2}+b^{2}\right] / 2}}{a b} .
$$

Solving for $h$ using measured values of $h_{\mathrm{d}}, w_{\mathrm{d}}, a$ and $b$ (Table 4) and average values of $\rho_{\mathrm{d}}$ and $\rho_{\mathrm{l}}$, the results range from an SWE layer exceeding $4 \mathrm{~cm}$ for the smaller lakes $(<100 \mathrm{ha})$, to layers less than $1 \mathrm{~cm}$ for the larger lakes
Table 3. Slopes of lines fitted to snow-depth data taken along east-west-heading probe lines showing increasing depth to the west

\begin{tabular}{|c|c|c|c|c|c|c|}
\hline Station & Intercept & Slope & $\begin{array}{c}95 \% \text { confideno } \\
\text { interval }\end{array}$ & Significant? & Direction & $\begin{array}{l}\text { Significant } \\
\text { gradients }\end{array}$ \\
\hline & & $\mathrm{cm} \mathrm{km}^{-1}$ & & & ${ }^{\circ}$ true & $\mathrm{cm} \mathrm{km}^{-1}$ \\
\hline OA-1 & 23.4 & 3.7 & \pm 0.0058 & No & & \\
\hline OA-5 & 18.8 & 12.0 & \pm 0.0076 & Yes & 222 & 12 \\
\hline OA-7 & 19.0 & 52.9 & \pm 0.0251 & Yes & 256 & 53 \\
\hline OA-10 & 18.0 & 5.5 & \pm 0.0028 & Yes & 273 & 5 \\
\hline OA-11 & 13.2 & 264.2 & \pm 0.5330 & No & & \\
\hline OA-13 & 17.3 & 1.7 & \pm 0.0032 & No & & \\
\hline OA-15 & 12.2 & 8.1 & \pm 0.0024 & Yes & 250 & 8 \\
\hline AB-1 & 21.8 & 13.6 & \pm 0.0128 & Yes (barely) & 268 & 14 \\
\hline AB-3 & 23.5 & 8.1 & \pm 0.0036 & Yes & 271 & 8 \\
\hline AB- 4 & 19.9 & -1.7 & \pm 0.0042 & No & & \\
\hline AB-5 & 21.3 & 35.1 & \pm 0.0154 & Yes & 250 & 35 \\
\hline $\begin{array}{l}\text { Imikpuk } \\
\text { Lake }\end{array}$ & 16.8 & 4.1 & \pm 0.0046 & No & & \\
\hline Average & & & & & 256 & 19 \\
\hline
\end{tabular}

( $>400$ ha). This range brackets the additional loss $(1.2 \mathrm{~cm})$ of SWE needed to balance the winter mass.

Stockpiling snow in drifts along the lake banks has another ramification: it produces the observed snow depletion along the windward edge of the lakes and snow depth profiles that increase downwind (Fig. 4). To investigate this effect, we implemented a simplified two-dimensional version of SnowTran-3D, a blowing-snow transport model (Liston and Sturm, 1998), on a cross-lake profile oriented parallel to the prevailing wind. The model is based on the mass-balance equation:

$$
\frac{\mathrm{d} h}{\mathrm{~d} t}=\frac{1}{\rho_{\mathrm{s}}}\left(-\frac{\mathrm{d} Q_{s}}{\mathrm{~d} x}\right),
$$

where $h$ is now snow depth in meters, $t$ is time, $x$ is the along-profile coordinate, $Q_{\mathrm{s}}$ is saltation transport (units: $\left.\mathrm{kg} \mathrm{m}^{-1} \mathrm{~s}^{-1}\right)$ and $\rho_{s}$ is snow density $\left(280 \mathrm{~kg} \mathrm{~m}^{-3}\right)$. We assume that the upwind bank traps and holds any snow blown into it, so that the saltation flux at the upwind edge of the lake (the downwind edge of the bank drift) is zero. Anyone who has sheltered in the lee of a cut-bank during an Arctic blizzard will recognize that this is a realistic assumption. With this zero-flux-upwind boundary condition and a constant wind-shear velocity (or wind speed) over the lake surface, the saltation flux is:

$$
Q_{\mathrm{s}}(x)=Q_{\mathrm{s}-\max }\left[1-\exp \left(-\mu \frac{x}{f}\right)\right],
$$

where $\mu(=3.0)$ is a non-dimensional scaling constant, $f$ is the equilibrium fetch distance, and $Q_{\text {s_max }_{\text {max }}}$ is the equilibrium (or fetch) saltation transport rate (assumed to be $0.01224 \mathrm{~kg} \mathrm{~m}^{-1} \mathrm{~s}^{-1}$ : see Liston and Sturm (1998) for details).

For the model simulations, we assumed there was a period without wind during which a $20 \mathrm{~cm}$ uniform snow cover was deposited on the lake. This was followed by a period of wind with no precipitation. We ran three cases $(f=250,500$ and $1000 \mathrm{~m}$ ), blowing the snow until the snow depth at the leading edge of the lake (downwind toe of the bank drift) was eroded down to $1 \mathrm{~cm}$ (Fig. 8), matching the observed average snow-depth gradient $\left(19 \mathrm{~cm} \mathrm{~km}^{-1}\right.$; Table 3$)$. 


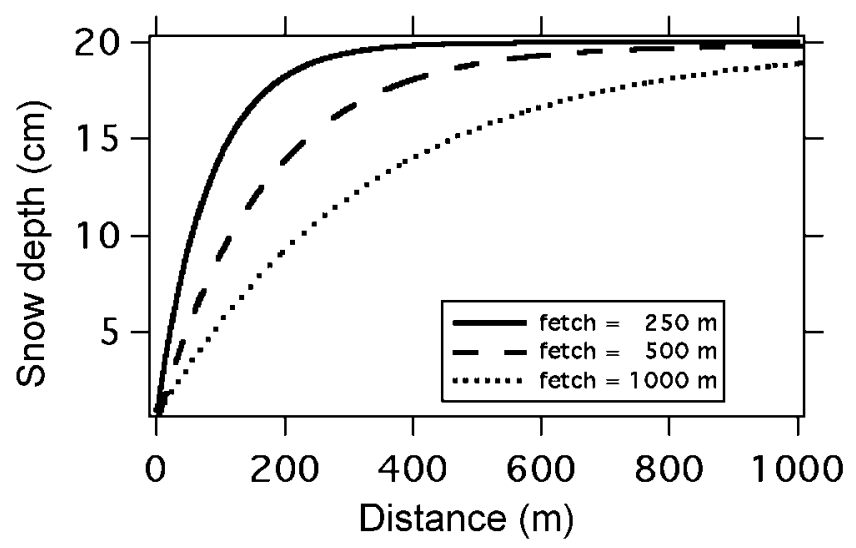

Fig. 8. Modeled snow depth on a lake, for wind flowing from left to right, with a bank drift at the left edge of the domain that effectively traps all of the upwind snow blowing into the lake. The snow depth varies with distance from the lake edge due to erosion. At the equilibrium fetch distance (the distance at which the snow transport is within 95\% of its equilibrium flux), erosion is matched by deposition and the depth does not change.

The model ran 4, 8 and 17 days, for the three fetch distances, respectively, before this point was reached. The $1000 \mathrm{~m}$ fetch distance best matched the observed profiles (Fig. 4). The model results, of course, are less noisy than the natural system, but the general trends are similar. Both observations and model suggest that the trapping of snow in lake-edge drifts is the cause of the east-west snow-depth gradients we observed on the lakes. The model simulations are also consistent with depth profiles measured from the western edges of large lakes where near-uniform snow depths were observed.

The model and our observations suggest that snow deposited in bank drifts balances the snow eroded from the lake surface, with the one caveat that the bank drifts can contain snow from the period before lake freeze-up. This leads us to conclude that the increased erosion from the lake surface which ends up in bank drifts, plus the snow falling into the water before it freezes, is sufficient to explain the difference in the mass balance between lakes and land. Sublimation, the one other possible "sink" for lake snow, seems unlikely to be important. For the sublimation to be greater over the lakes, the general wind speed over lakes would need to be higher than over the flat tundra. There is currently no evidence for this general difference, but, as we discuss below, localized areas of higher wind speeds are almost certainly present on the lakes (a consequence of surface roughness differences), and these local wind effects are responsible for some of the key contrasts between lake and land snow: namely, that the snow on the lakes is harder, denser and often accumulates into larger dunes.

The source of local snow erosion/deposition that produces the relatively large lake dunes is the variation of wind speed over bare ice and snow-covered ice. Consider a lake that has recently frozen and on which a thin snowfall has been deposited. Turbulent wind fluctuations will redistribute this snow irregularly, creating a mosaic of snow-covered and snow-free areas. We do not completely understand the mechanisms that lead to this initial patchy distribution, but we have seen the resulting patterns many times. To be consistent with Figure $6 \mathrm{~b}$ and images like Figure 9, we assume that the dunes and bare patches have characteristic lengths of about $6 \mathrm{~m}$, producing a surface which in the downwind direction has alternating bands of snow and ice

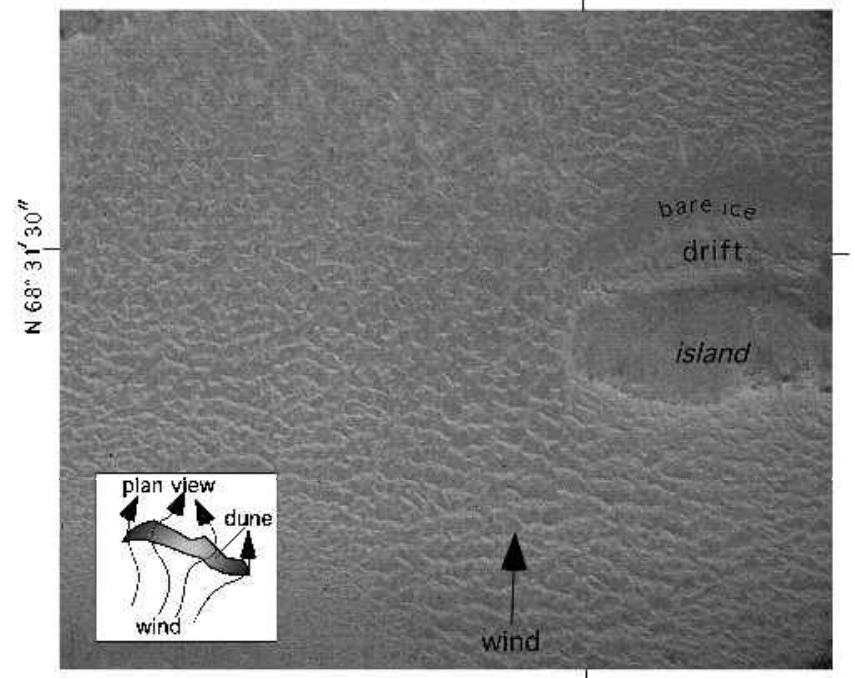

W $149^{\circ} 28^{\prime} 30^{\prime \prime}$

Fig. 9. Oblique aerial photograph of snowdrifts on lake ice in arctic Alaska. The light-colored ripple patterns are snowdrifts, and the darker areas are the bare lake ice. The wind has been blowing from the bottom to top of the picture. The smooth bump on the right is an island in the lake. It has created a drift and bare ice area much like that formed by a bank at the edge of a lake. For scale, the distance across the island from top to bottom is about $100 \mathrm{~m}$. The inset suggests the complex nature of the true flow of wind over and around individual dunes.

with a $12 \mathrm{~m}$ wavelength. Using a two-dimensional dynamic wind model (Liston and others, 1994), and assuming a logarithmic wind profile $\left(10 \mathrm{~m} \mathrm{~s}^{-1}\right.$ at $10 \mathrm{~m}$ height $)$ and ice and snow roughness lengths of 0.00001 and $0.001 \mathrm{~m}$, respectively (see Berry, 1981), we computed wind speeds along the downwind profile. The model results indicate near-surface wind speeds ( $5 \mathrm{~cm}$ height) as much as $15 \%$ higher over bare ice than over snow-covered ice (Fig. 10). The enhancement is limited to a layer not much higher than the dunes themselves, because $1 \mathrm{~m}$ above the surface the speed is nearly uniform. This vertical speed distribution requires a complex three-dimensional wind pattern (necessary for conservation of mass and momentum) with higher speeds over bare ice patches and flow over and around the dunes (inset, Fig. 9).

Over bare ice patches where the wind is stronger and

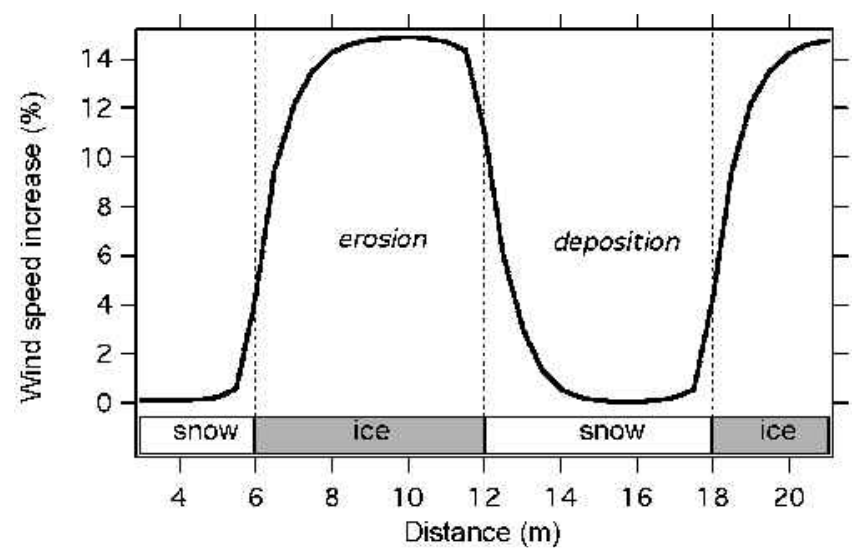

Fig. 10. Near-surface wind-speed variations over alternating bands of snow and bare lake ice, showing zones of erosion and deposition that tend to enhance the growth of drifts and perpetuate the bare-ice patches. 
Table 4. Lake size ( $a$ and $b$ ), perimeter, area, and drift size ( $h_{\mathrm{d}}$ and $w_{\mathrm{d}}$ ), with computed thickness ( $h$ ) of layer if drift was spread evenly over the lake surface

\begin{tabular}{|c|c|c|c|c|c|c|c|c|}
\hline Station & $\begin{array}{c}\text { Area } \\
\text { ha }\end{array}$ & $\begin{array}{l}h_{\mathrm{d}} \\
\mathrm{m}\end{array}$ & $\begin{array}{l}w_{\mathrm{d}} \\
\mathrm{m}\end{array}$ & $\begin{array}{l}a \\
\mathrm{~m}\end{array}$ & $\begin{array}{l}b \\
\mathrm{~m}\end{array}$ & $\begin{array}{c}\rho_{\mathrm{d}} \\
\mathrm{g} \mathrm{cm}^{-3}\end{array}$ & $\begin{array}{c}\rho_{\mathrm{l}} \\
\mathrm{g} \mathrm{cm}^{-3}\end{array}$ & $\begin{array}{l}h \\
\mathrm{~cm}\end{array}$ \\
\hline OA-1 & 123 & 1.3 & 28 & 1358 & 1157 & 0.45 & 0.35 & 3.8 \\
\hline OA-5 & 114 & 1.3 & 30 & 1257 & 1157 & 0.45 & 0.35 & 4.2 \\
\hline OA-7 & 906 & 0 & 0 & 3822 & 3018 & 0.45 & 0.35 & 0.0 \\
\hline OA-10 (2000) & 6 & - & - & 402 & 201 & 0.45 & 0.35 & 4.0 \\
\hline OA-10 (2002) & 248 & 0.4 & 20 & 2615 & 1207 & 0.45 & 0.35 & 0.7 \\
\hline OA-11 & 31 & 0.54 & 25 & 553 & 704 & 0.45 & 0.35 & 2.8 \\
\hline OA-13 & 57 & 0.45 & 24 & 604 & 1207 & 0.45 & 0.35 & 1.8 \\
\hline OA-15 & 826 & 0.55 & 28 & 4023 & 2615 & 0.45 & 0.35 & 0.6 \\
\hline AB-1 & 24 & 0.81 & 22 & 604 & 503 & 0.45 & 0.35 & 4.2 \\
\hline AB-2 & 122 & - & - & 1106 & 1408 & 0.45 & 0.35 & 1.9 \\
\hline AB-3 & 219 & 0.39 & 18 & 2313 & 1207 & 0.45 & 0.35 & 0.6 \\
\hline AB-4 & 8 & 0.55 & 22 & 352 & 302 & 0.45 & 0.35 & 4.8 \\
\hline AB-5 & 157 & - & - & 2213 & 905 & 0.45 & 0.35 & 1.3 \\
\hline Imikpuk Lake & 61 & 0.64 & 25 & 1106 & 704 & 0.45 & 0.35 & 2.4 \\
\hline Average values & & 0.63 & 22 & 1595 & 1164 & & & 2.4 \\
\hline
\end{tabular}

accelerating, erosion is favored and the ice patches will tend to remain snow-free. Over existing snow dunes, where the opposite conditions prevail, accumulation will take place. Though not modeled here, form drag will also enhance snow accumulation on the dune's lee side, contributing to the growth. Dunes will get bigger, and bare patches will remain until snowfall exceeds the wind's ability to completely erode snow from the patches. Once formed, the dunes will continue to modify the wind field and associated erosion/deposition, and thus perpetuate themselves throughout the winter.

\section{IMPLICATIONS}

The thinner, denser, more wind-blown snow found on lakes of the ACP is a much poorer thermal insulator than the snow on adjacent tundra, a difference that has implications for lake ice formation, the ACP winter energy balance, and possibly lake life cycles. To quantify this difference, we computed the bulk thermal resistance of a typical lake snow cover and compared it to the thermal resistance of a typical land snow cover. Using average snow depths and densities (Table
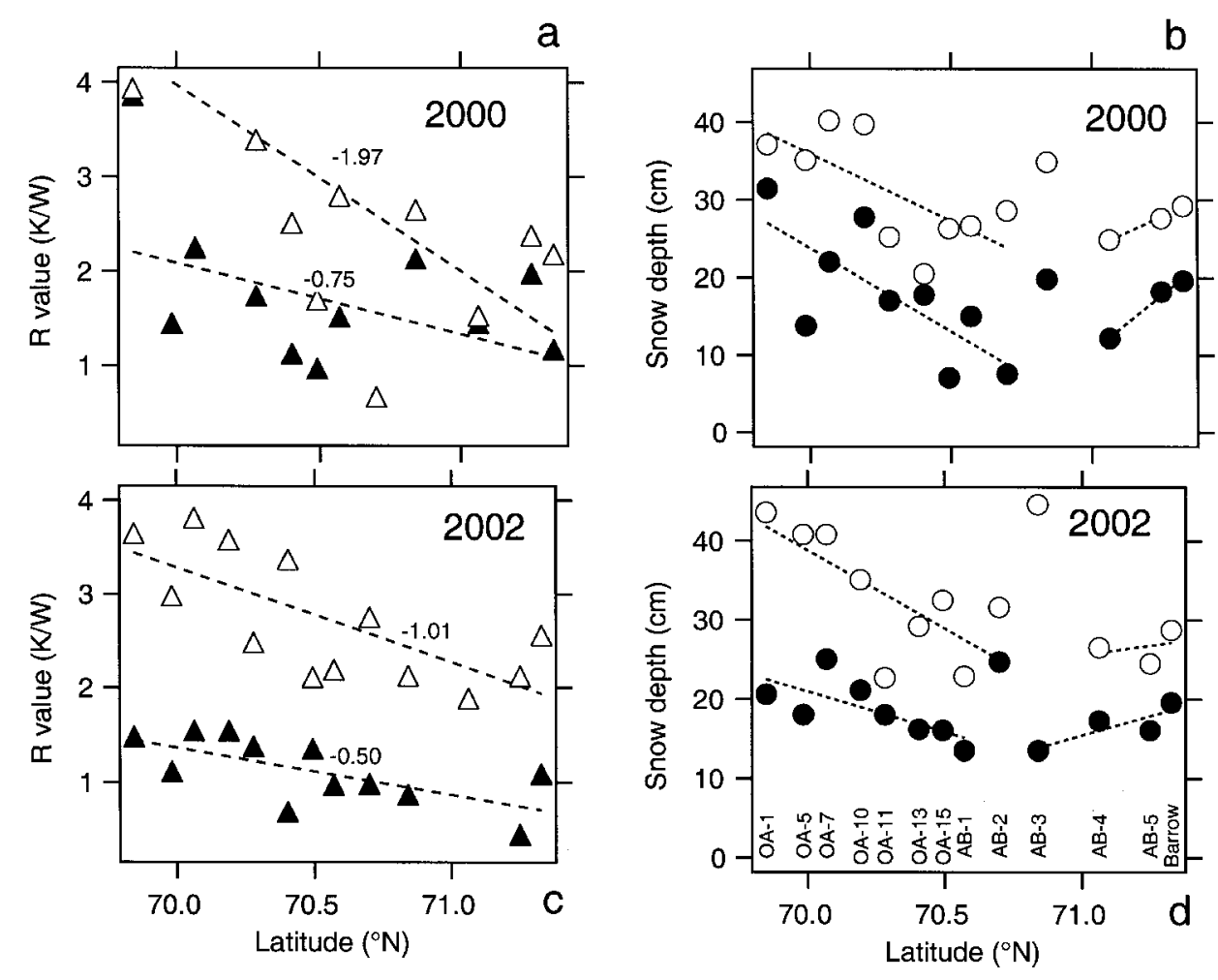

Fig. 11. (a, c) Variation in lake and land snow thermal resistance ( $R$ ) with latitude in 2000 (a) and 2002 (c), showing a decrease from south to north, but no minimum. The slopes of the lines (change in $R$ value per degree of latitude) are marked. Open symbols are for land, solid symbols for lakes. (b,d) Variation in lake and land snow depths with latitude in 2000 (b) and 2002 (d), showing a decrease from south to north to a minimum at $70.8^{\circ} \mathcal{N}$, followed by a slight increase to the coast at Barrow. Open symbols are for land, solid symbols for lakes. Stations are indicated at the bottom of $(d)$. 
1), additional data from 1996 collected near Prudhoe Bay, and a regression equation for density vs thermal conductivity (Sturm and others, 1997), we found that lake snow had a thermal insulation value that was about $40 \%$ that of land snow. We further refined this comparison by directly incorporating the textural results from Figure 2 into our calculations. Using the layer proportions in Figure 2 for the snow cover on both lakes and land, and depths from Table 1, we obtained bulk thermal conductivity values $\left(k_{\mathrm{b}}\right)$ of 0.119 vs $0.222 \mathrm{~W} \mathrm{~m}^{-1} \mathrm{~K}^{-1}$ for lakes and land, respectively. The values were computed for 2001 using a series-type solution for layered media. Similar values were obtained in 2002. In both cases, lake snow had a thermal insulation value that was $54 \%$ that of land snow.

The poor insulating value of ACP lake snow was experienced by Jeffries and others (1999) and Zhang and Jeffries (2000) when they found spring heat-flow rates 12 times higher on lakes than on the nearby tundra. To tune their lake ice growth model to match observed ice thicknesses, they had to apply a factor to weather-station snow-depth records (land snow) that ranged from 0.34 to 0.88 , a procedure that effectively decreased the thermal insulation value of lake snow by a factor consistent with the results of our study. When they did not apply the factor, Zhang and Jeffries' model underestimated ice growth by $35-65 \mathrm{~cm}$. One conclusion is clear: if lake snow is not differentiated from tundra snow in models, serious underestimates of heat flow and ice thickness will result.

A simple, constant correction factor for lake snow cannot be used, however, because the thermal insulation of both land and lake snow varies by a factor of 2 across the ACP (Fig. 1la and c). We tracked this variation using thermal resistance $(R)$, which has units of $\mathrm{KW}^{-1}$ and is a quantity that combines snow depth and thermal conductivity:

$$
R=\sum_{\text {layers }} \frac{\phi_{i}}{k_{i} A},
$$

where $\phi_{i}$ is the thickness of the $i$ th layer, $k_{i}$ is the thermal conductivity of that layer, $A$ is the area $\left(\mathrm{m}^{2}\right)$, and the summation is over all layers in the snowpack. $R$ values were highest in the south and decreased with distance north, reaching a minimum at the coast near Barrow. In 2002, for example, $R$ for lakes (solid symbols in Fig. 1la and c) decreased from about 1.5 to $0.8 \mathrm{KW}^{-1}$ across the ACP. In 2000, the trends were of similar magnitude and slope, though not as clearly defined. These gradients mean that for a set of constant winter environmental conditions (i.e. temperature, wind, radiation, etc.), $50 \mathrm{~cm}$ more lake ice would have grown at the north end of the ACP than at the south end.

The variation of $R$ with latitude is not solely a function of snow depth (Fig. 1lb and d). Depth decreased with distance north (both 2000 and 2002), reaching a minimum at $70.8^{\circ} \mathrm{N}$, followed by a subtle but significant increase to the coast. This V-shaped pattern is not preserved in the trends for $R$. We have observed a similar $V$-shaped pattern to the snow depth on south-north transects in the Kuparuk Basin south of Prudhoe Bay (Liston and Sturm, 2002; Taras and others, 2002). A consistent regional snow texture trend must offset the depth minimum. Based on our knowledge of snow thermal properties (Sturm and others, 1997), this is likely to be an increase in wind slab and a decrease in depth hoar with distance north, but the stratigraphic data for individual stations (cf. Fig. 3) are too noisy to identify these trends with certainty.

One ramification of consistent and strong regional $R$ gradients across the ACP is that lake bathymetry determined using spaceborne radar may require reassessment. Using synthetic aperture radar (SAR), it is possible to distinguish lakes that have floating ice covers from those frozen to their beds (Sellman and others, 1975; Weeks and others, 1978; Jeffries and others, 1996; Kozlenko and Jeffries, 2000). Using a sequence of SAR images, it is possible to estimate the day the lakes freeze to their beds, and to then invert the elapsed time into an ice thickness value and lake depth. The method hinges on accurately modeling the lake-freezing rate, which is first-order sensitive to the lake snow amount (Zhang and Jeffries, 2000). Recent studies have used Barrow weather data and assumed a constant freezing rate across the ACP (Jeffries and others, 1996; Kozlenko and Jeffries, 2000). A higher percentage of lakes not frozen to their bed in the southern ACP has led to the conclusion that more of these lakes are deeper than $2.2 \mathrm{~m}$ (depth of maximum freeze before spring thaw) than in the northern part. Our results suggest an alternate interpretation: lakes in the southern ACP freeze slower due to a more insulative snow cover, producing less ice per unit time than in the northern ACP.

Lastly, we would like to speculate that the minimum snow depths found on the eastern side of the lakes (Figs 4 and 5) may play a role in their evolution and life cycle. The snow minimum is the result of the same prevailing wind that has been shown (Carson and Hussey, 1962) to be the cause of the remarkable orientation of the lakes (Fig. 1). On the eastern side where snow is thinnest, the ice grows thicker and there is greater winter frost penetration into the banks and bed of the lake. Thicker ice lasts longer into the summer (Carson and Hussey estimate 3-6 weeks longer), and more solidly frozen banks and bed will resist thermal and mechanical erosion better and longer into summer. Because the lakes are basically thermo-erosional features (Black and Barksdale, 1949; Carson and Hussey, 1962; Black, 1969; Sellman and others, 1975; Hinkel and others, in press), the localized thermal impact due to east-side snow scouring may be important enough to warrant further study.

\section{GONGLUSIONS}

Lake snow cover of Alaska's ACP is thinner, denser and composed of more wind slab and less depth hoar than snow on surrounding land. The SWE is also lower. Consequently, lake snow provides less than half the thermal insulation of land snow, leading to more rapid lake-ice formation rates than would be predicted if the characteristics of land snow were used for lake modeling. The reduced lake snow thickness and SWE arises from (1) loss of snow precipitation into the water early in the winter, (2) stockpiling of snow along lake banks during wind drifting, and (3) snow-depth depletion along the eastern side of the lakes due to non-equilibrium blowing-snow fluxes. Consistent south-north snow-depth and snow-insulation trends exist across the ACP, with greater depths, and insulation values almost twice as high in the south end of the $\mathrm{ACP}$ as in the north. These regional gradients may account for apparent lake depth differences reported using SAR and lake-freezing models. The lower snow depths, poorer insulation and regional gradients in these snow properties should be used when modeling ACP lake ice formation and winter surface energy fluxes. 


\section{ACKNOWLEDGEMENTS}

J. Holmgren and K. Tape participated in all over-snow traverses and provided invaluable assistance. E. Pyne and A. Cheuvront helped in the field in 2002. M. Jeffries and C. Benson encouraged us in this work. T. Douglas made valuable comments on an earlier version of this paper. Logistical support was provided by the Barrow Arctic Science Consortium (D. Ramey and G. Sheehan), the Bureau of Land Management (M. Kunz) and Veco Polar Resources (M. Kuizenga). The work was funded by a grant from the U.S. National Science Foundation's Office of Polar Programs (OPP-9732077) and by the U.S. Army Cold Regions Research and Engineering Laboratory. J. Glen's handling the paper as Scientific Editor and the comments of reviewers W. Weeks and C. Benson are greatly appreciated.

\section{REFERENGES}

Akitaya, E. 1974. Studies on depth hoar. Contrib. Inst. Low Temp. Sci., Ser. A 26.

Benson, C. S. and M. Sturm. 1993. Structure and wind transport of seasonal snow on the Arctic slope of Alaska. Ann. Glaciol., 18, 261-267.

Berry, M. O. 1981. Snow and climate. In Gray, D. M. and D. H. Male, eds. Handbook of snow: principles, processes, management and use. Toronto, Ont., Pergamon Press Canada Ltd., 32-59.

Bilello, M. A. 1980. Maximum thickness and subsequent decay of lake, river and fast sea ice in Canada and Alaska. CRREL Rep. 80-6.

Bilello, M. A., R. E. Bates and G. Hadlock. 1964. Ice thickness observations, North American Arctic and Subarctic, 1960-61, 1961-62. CRREL Spec. Rep. 43.

Black, R. F. 1969. Thaw depressions and thaw lakes - a review. Biul. Peryglac., 19, $131-150$.

Black, R. F. and W. L. Barksdale. 1949. Oriented lakes of northern Alaska. F. Geol., 57(2), 105-118.

Brewer, M. C. 1958. The thermal regime of an Arctic lake. Transactions, American Geophysical Union, 39(2), 278-284.

Carson, C. E. and K. M. Hussey. 1962. The oriented lakes of Arctic Alaska. 7. Geol., $70(4), 417-439$.

Colbeck, S. C. 1986. Classification of seasonal snow cover crystals. Water Resour. Res., 22(9), 59S-70S.

Colbeck, S. C. and 7 others. 1990. The international classification for seasonal snow on the ground. Wallingford, Oxfordshire, International Association of Scientific Hydrology. International Commission on Snow and Ice.

German, R. M. 1996. Sintering theory and practice. New York, etc., John Wiley \& Sons, Inc.

Hinkel, K. M., W. R. Eisner, J. G. Bockheim, F. E. Nelson, K. M. Peterson and X. Dai. In press. Spatial extent, age and carbon stocks in drained thaw lake basins on the Barrow Peninsula, Alaska. Arct. Antarct. Alp. Res.

Holmgren, J., M. Sturm, N. E. Yankielun and G. Koh. 1998. Extensive measurements of snow depth using FM-CW radar. Cold Reg. Sci. Technol., 27(1), 17-30.

Jeffries, M. O., K. Morris and G. E. Liston. 1996. A method to determine lake depth and water availability on the North Slope of Alaska with spaceborne imaging radar and numerical ice growth modelling. Arctic, 49(4), 367-374
Jeffries, M. O., T. Zhang, K. Frey and N. Kozlenko. 1999. Estimating latewinter heat flow to the atmosphere from the lake-dominated Alaskan North Slope. 7. Glaciol., 45(150), 315-324. (Erratum: 45(151), p. 589.)

König, M. and M. Sturm. 1998. Mapping snow distribution in the Alaskan Arctic using aerial photography and topographic relationships. Water Resour. Res., 34(12), 3471-3484.

Kozlenko, N. and M. O. Jeffries. 2000. Bathymetric mapping of shallow water in thaw lakes on the North Slope of Alaska with spaceborne imaging radar. Arctic, 53, 306-316.

Liston, G. E. and D. K. Hall. 1995. An energy-balance model of lake-iceevolution. F. Glaciol., 41 (138), 373-382.

Liston, G. E. and M. Sturm. 1998. A snow-transport model for complex terrain. F. Glaciol., 44(148), 498-516.

Liston, G. E. and M. Sturm. 2002. Winter precipitation patterns in arctic Alaska determined from a blowing-snow model and snow-depth observations. Hydrometeorology, 3(6), 646-659.

Liston, G. E., R. L. Brown and J. Dent. 1994. A two dimensional computational model of turbulent atmospheric surface flows with drifting snow. Ann. Glaciol., 18.

Olsson, P. Q., L. D. Hinzman, M. Sturm, G. E. Liston and D. L. Kane. 2002. Surface climate and snow-weather relationships of the Kuparuk Basin on Alaska's Arctic Slope. Ft. Belvoir,VI, U.S. Army ERDC/CRREL. (ReportTR-02-10.)

Olsson, P. Q., M. Sturm, C. H. Racine, V. Romanovsky and G. E. Liston. 2003. Five stages of the Alaskan Arctic cold season with ecosystem implications. Arct. Antarct. Alp. Res., 35 (1), 74-81.

Sellmann, P.V., J. Brown, R. I. Lewellen, H. McKim and C. Merry. 1975. The classification and geomorphic implications of thaw lakes on the Arctic Coastal Plain. CRREL Res. Rep. 344.

Sturm, M. and C. S. Benson. 1997. Vapor transport, grain growth and depth-hoar development in the subarctic snow. F. Glaciol., 43(143), 42-59.

Sturm, M. and J. Holmgren. 1994. Effects of microtopography on texture, temperature and heat flow in Arctic and sub-Arctic snow. Ann. Glaciol., 19, 63-68.

Sturm, M. and J. Holmgren, 1999. Self-recording snow depth probe. U.S. Patent 5,864,059 (Assigned to U.S. Army Corps of Engineers. Cold Regions Research and Engineering Laboratory.)

Sturm, M., J. Holmgren and G. E. Liston. 1995. A seasonal snow cover classification scheme for local to global applications. 7. Climate, 8(5), Part 2, $1261-1283$.

Sturm, M., J. Holmgren, M. König and K. Morris. 1997. The thermal conductivity of seasonal snow. F. Glaciol., 43(143), 26-41.

Sturm, M., K. Morris and R. Massom. 1998. The winter snow cover of the West Antarctic pack ice: its spatial and temporal variability. In Jeffries, M. O., ed. Antarctic sea ice: physical processes, interactions and variability. Washington, DC, American Geophysical Union, 1-18. (Antarctic Research Series 74.)

Sturm M., G. E. Liston, C. S. Benson and J. Holmgren. 2001. Characteristics and growth of a snowdrift in Arctic Alaska, U.S.A. Arct. Antarct. Alp. Res., 33 (3), 319-329.

Taras, B., M. Sturm and G. E. Liston. 2002. Snow-ground interface temperatures in the Kuparuk River basin, Arctic Alaska: measurements and model. Hydrometeorology, 3(4), 377-394.

Weeks, W. F., A. G. Fountain, M. L. Bryan and C. Elachi. 1978. Differences in radar return from ice-covered North Slope lakes. 7. Geophys. Res., 83(C8), 4069-4073.

Zhang, T. and M. O. Jeffries. 2000. Modeling interdecadal variations of lake-ice thickness and sensitivity to climatic change in northernmost Alaska. Ann. Glaciol., 31, 339-347. 